\title{
APPLICATION OF REDUCED RATES OF ACCase- INHIBITING HERBICIDES TO SUNFLOWER INTERCROPPED WITH Brachiaria ruziziensis
}

\author{
Brighenti, A.M. ${ }^{*}$, Rocha, W.S.D. ${ }^{1}$, Souza Sobrinho, F. ${ }^{1}$, Castro, C. ${ }^{2}$, \\ Martins, C.E. ${ }^{1}$ and Muller, M.D. ${ }^{1}$
}

${ }^{1}$ Embrapa Dairy Cattle, Rua Eugênio do Nascimento, n. 610, B. Dom Bosco, Juiz de Fora, Minas Gerais State, Brazil

${ }^{2}$ Embrapa Soybean, Rod. Carlos João Strass/Orlando Amaral,

Londrina, Paraná State, Brazil

Received: June 23, 2010 Accepted: January 25, 2011

\section{SUMMARY}

The objective of this study was to evaluate the tolerance of sunflower (Helianthus annuus) to acetyl-coenzyme A carboxylase (ACCase)-inhibiting herbicides and to temporarily delay the growth of the forage grass (Brachiaria ruziziensis), avoiding competition and allowing the reestablishment of pasture. A randomized block design with four replicates was used in both experiments. The following treatments were applied in Experiment 1:

I) $10 \mathrm{~g}$ ai ha ${ }^{-1}$ tepraloxydim; II) $20 \mathrm{~g}$ ai ha $\mathrm{ha}^{-1}$ tepraloxydim; III) $12.5 \mathrm{~g}$ ai ha ${ }^{-1}$ fluazifop-p-butyl; Iv) $25 \mathrm{~g}$ ai ha ${ }^{-1}$ fluazifop-p-butyl; v) $12 \mathrm{~g}$ ai ha ${ }^{-1}$ clethodim; vI) $24 \mathrm{~g}$ ai ha-1 clethodim; vII) $6 \mathrm{~g}^{-1}$ ai ha $^{-1}$ haloxyfop-methyl; vIII) $12 \mathrm{~g}$ ai ha ${ }^{-1}$ haloxyfop-methyl; IX) unhoed check, and x) hoed check.

The treatments applied in Experiment 2 were:

I) hoed check; II) unhoed check; III) $10 \mathrm{~g}$ ai ha ${ }^{-1}$ tepraloxydim; IV) $20 \mathrm{~g}$ ai $\mathrm{ha}^{-1}$ tepraloxydim; v) $12.5 \mathrm{~g}$ ai ha ${ }^{-1}$ fluazifop-p-butyl, and vi) $25 \mathrm{~g}$ ai ha ${ }^{-1}$ fluazifop-p-butyl.

All herbicide treatments were selective for the sunflower crop. The use of reduced rates of graminicides is a feasible option to delay the growth of $B$. ruziziensis, reducing its ability to compete the sunflower. All herbicide rates applied suppressed the growth of $B$. ruziziensis, permitting subsequent pasture reestablishment. However, tepraloxydim $\left(20 \mathrm{~g}_{\text {ai ha }}{ }^{-1}\right)$, clethodim (24 g ai $\mathrm{ha}^{-1}$ ), and haloxyfop-methyl ( $12 \mathrm{~g}$ ai ha ${ }^{-1}$ ) promoted poorer recovery of the forage grass.

Key words: $\quad$ Clearfield $^{\circledR}$, integrated crop-livestock systems, sustainable intensification

* Corresponding author: Phone: +055 323311 7470; e-mail: brighent@cnpgl.embrapa,br 


\section{INTRODUCTION}

The exploitation of annual crops characterized by intense mechanization and non-selective use of agrochemicals may damage physical and chemical properties of soil, leading to soil compaction, destructuring and reduced organic content. In addition, this approach may increase the number of damaging biotic agents in cultivation, with a consequent reduction of productivity and intensified application of agricultural defenders. Furthermore, in farming areas the inadequate management of forage grasses, especially the lack of application of maintenance fertilizers and overgrazing, results in a critical stage of pasture degradation (Brighenti et al., 2007).

The adoption of integrated crop-livestock (CLI) systems provides various benefits. Pastures utilize residues of fertilizers applied to crops and recycle nutrients from deeper layers due to their abundance and greater depth of their roots. Pastures are also excellent accumulators of biomass, enriching the soil with organic matter. The increased organic content, in turn, favors the storage of water and increases the activity of soil microorganisms and soil fauna (Martius et al., 2001), contributing to soil aggregation and consequently reducing erosion and superficial runoff.

Tropical forage plants are mainly known for their adaptation and tolerance to damaging biotic factors that affect annual crops, interrupting the cycle of life of pests and diseases. Grass has contributed to reduction of the intensity of attacks made by diseases, such as white mold and root rot caused by Rhizoctonia solani and Fusarium solani in bean crops (Kluthcouski et al., 2000). A significant reduction in the occurrence of weeds has also been reported (Cobucci et al., 2001). Another positive biological effect of CLI is the reduction of soil nematodes (Vilela et al., 1999, 2003). This system also benefits the association of arbuscular mycorrhizal fungi with roots, increasing the capacity of plants to absorb soil nutrients, especially phosphorus, and thus improving the response of the plant to different fertilizers (Miranda et al., 2001). In addition to pasture production, forage species serve as a soil cover for no-till systems. Corn-grass intercropping can produce up to 17 tons of dry matter per hectare (Aidar et al., 2000).

In CLI systems, the correct application of both pre-sowing and post-cultivation herbicides is of fundamental importance for the establishment of the intercrop system (Kluthcouski et al., 2000). The use of reduced rates of acetyl-coenzyme A carboxylase (ACCase)-inhibiting herbicides has been shown to promote a satisfactory control of some grass infestations and cultivation of tropical forages with annual crops (Silva et al., 2004, 2006a, 2006b). These herbicides block the biosynthesis of lipids by the plants (Konishi et al., 1996). As a consequence, the growth of roots and aerial parts is suppressed, resulting in abnormal leaf pigmentation and initiating a necrotic process in meristematic regions (Gronwald, 1991). 
The determination of sublethal rates of herbicides is necessary to temporarily delay the growth of the forage plant and prevent competition with the crop plantation, as well as to allow subsequent pasture reestablishment. The objective of the present study was to evaluate the tolerance of sunflower (Helianthus annuus) to ACCase-inhibiting herbicides and to temporarily delay the growth of the forage grass (Brachiaria ruziziensis), avoiding competition with the sunflower plantation and permitting subsequent pasture reestablishment.

\section{MATERIAL AND METHODS}

Experiment 1: The experiment was installed on June 5, 2008, on the Experimental Field of Embrapa Dairy Cattle, municipality of Valença $\left(22^{\circ} 21^{\prime} 28^{\prime \prime} \mathrm{S}\right.$ and $43^{\circ} 41^{\prime} 45^{\prime}$ W), Rio de Janeiro State, Brazil. A randomized block design with four replicates was used. The following treatments were applied:

I) $10 \mathrm{~g}$ ai ha- $\mathrm{ha}^{-1}$ tepraloxydim; II) $20 \mathrm{~g}_{\text {ai }} \mathrm{ha}^{-1}$ tepraloxydim; III) $12.5 \mathrm{~g}$ ai ha- $\mathrm{hlu}^{-1}$ azifop-p-butyl; IV) $25 \mathrm{~g}$ ai ha ${ }^{-1}$ fluazifop-p-butyl; v) $12 \mathrm{~g}$ ai ha ${ }^{-1}$ clethodim; vI) $24 \mathrm{~g}$ ai ha $^{-1}$ clethodim; VII) $6 \mathrm{~g}$ ai ha ${ }^{-1}$ haloxyfop-methyl; VIII) $12 \mathrm{~g}$ ai ha ${ }^{-1}$ haloxyfop-methyl; IX) unhoed check and X) hoed check.

Mineral oil $(0.5 \%, \mathrm{v} / \mathrm{v})$ was added to the herbicide treatments, except for the treatments with fluazifop-p-butyl. The soil was ploughed and harrowed and $15 \mathrm{~kg}$ $\mathrm{ha}^{-1}$ B. ruziziensis seeds (cultural value of $33 \%$ ) were manually sown and incorporated by using a harrow. The area was furrowed with a $0.70 \mathrm{~m}$ space between rows and fertilization at the sowing time consisted of $300 \mathrm{~kg} \mathrm{ha}^{-1}$ NPK formulation (8-2816) plus $1.2 \mathrm{~kg} \mathrm{ha}^{-1}$ boric acid, distributed inside the furrows. An imidazolinoneresistant sunflower genotype (Paraiso $102 \mathrm{CL}$, Clearfield ${ }^{\circledR}$ ) was sown and a plant stand of approximately 55,000 plants $\mathrm{ha}^{-1}$ was maintained. Side-dressing was performed with $250 \mathrm{~kg} \mathrm{ha}^{-1}$ NPK (20-05-20) applied 25 days after sowing (DAS). The herbicide treatments were applied on July 24, 2008, with a hand sprayer kept at a constant pressure of compressed $\mathrm{CO}_{2}(196 \mathrm{kPa})$. The sprayer bar was $1.5 \mathrm{~m}$ long and consisted of four flat-fan nozzles (110 02) spaced $0.5 \mathrm{~m}$ apart, with a spray volume of $170 \mathrm{l} \mathrm{ha}^{-1}$. On the occasion of herbicide application, the forage grass presented two tillers and a mean height of $15-20 \mathrm{~cm}$ and the sunflower plants were at phenological stage $\mathrm{V}_{6}$. The percentage of phytotoxicity to the sunflower plants and percentage of $B$. ruziziensis control were evaluated at 12, 28 and 40 days after herbicide application (DAHA), with zero corresponding to no visual injury symptom on the sunflower plants and no forage control, and 100\% corresponding to death of the sunflower and forage plants (SBCPD, 2005). The density and height of the forage grass were evaluated at 64 and 80 DAS, respectively. In addition, the fresh and dry phytomass of the forage plants was determined at 95 DAS in a square area of 0.25 $\mathrm{m}^{2}$ and the results were transformed into $\mathrm{kg} \mathrm{ha}^{-1}$. The fresh phytomass of the forage grass was also measured at 25 days after sunflower harvest to evaluate the capacity of pasture reestablishment. Fresh phytomass and seed productivity of sunflower were evaluated at 110 and 120 DAS, respectively. The data were submitted to ANOVA and means were compared by the Scott-Knott test at a level of probability of $5 \%$. 
Experiment 2: The experiment was installed on the Experimental Field of Embrapa Dairy Cattle, municipality of Coronel Pacheco $\left(21^{\circ} 33^{\prime} 22^{\prime \prime} \mathrm{S}\right.$ and $43^{\circ} 16^{\prime} 15$ ” W), Minas Gerais State, Brazil, on June 12, 2009. A randomized block design with four replicates was used. The following treatments were applied:

I) hoed check; II) unhoed check; III) $10 \mathrm{~g}$ ai ha ${ }^{-1}$ tepraloxydim; IV) $20 \mathrm{~g}$ ai ha ${ }^{-1}$ tepraloxydim; v) $12.5 \mathrm{~g}$ ai ha ${ }^{-1}$ fluazifop-p-butyl and vI) $25 \mathrm{~g}$ ai ha ${ }^{-1}$ fluazifop-pbutyl.

Mineral oil $(0.5 \%, \mathrm{v} / \mathrm{v})$ was added to the tepraloxydim treatments. The soil was prepared as described for Experiment 1. Common sunflower (Aguará 4 hybrid) was sown and the plants were selected to a stand of approximately 55,000 plants ha ${ }^{-1}$. Side-dressing was performed with $250 \mathrm{~kg} \mathrm{ha}^{-1} \mathrm{NPK}$ (20-05-20) applied 25 DAS. The herbicide treatments were applied approximately 25 days after sunflower sowing by using a hand sprayer which maintained a constant $\mathrm{CO}_{2}$ pressure of $196 \mathrm{kPa}$. The sprayer bar was 1.5 long and contained four flat-fan nozzles ( 11002 ) spaced $0.5 \mathrm{~m}$ apart, with a sprayer volume of $150 \mathrm{l} \mathrm{ha}^{-1}$. On the occasion of herbicide application, the forage grass presented two tillers and a mean height of $15 \mathrm{~cm}$ and the sunflower plants were at phenological stage $\mathrm{V}_{6}$. The percentage of phytotoxicity to the sunflower plantation and percentage of $B$. ruziziensis control were evaluated at 14, 21 and 40 DAHA using the same procedures as described for Experiment 1. The height of the sunflower plants was determined at 90 DAS and forage density and height at 64 DAS. In addition, fresh and dry phytomass of the forage grass was determined at 95 DAS in a square area of $0.25 \mathrm{~m}^{2}$ and the results were transformed into $\mathrm{kg} \mathrm{ha}^{-1}$. Fresh phytomass of sunflower was evaluated at 110 DAS. The fresh phytomass of the forage grass was again measured at 25 days after sunflower harvest to evaluate the capacity of pasture reestablishment. Statistical analysis was the same as that described for Experiment 1.

\section{RESULTS AND DISCUSSION}

Experiment 1: None of the herbicides or herbicide rates applied caused symptoms of phytotoxicity in sunflower (Table 1).

Table 1: Mean percentage of phytotoxicity to the sunflower plants and percentage of control of B. ruziziensis at 12,28 and 40 days after herbicide application (DAHA).

\begin{tabular}{|c|c|c|c|c|c|c|}
\hline \multirow{2}{*}{ Treatment } & \multicolumn{3}{|c|}{ \% Phytotoxicity } & \multicolumn{3}{|c|}{$\%$ Control } \\
\hline & $12 \mathrm{DAHA}$ & $28 \mathrm{DAHA}$ & 40 DAHA & 12 DAHA & 28 DAHA & $40 \mathrm{DAHA}$ \\
\hline Tepraloxydim $10 \mathrm{~g}_{\text {ai }} \mathrm{ha}^{-1}$ & 0.0 & 0.0 & 0.0 & 10.0 & 5.0 & 0.0 \\
\hline Tepraloxydim $20 \mathrm{~g}_{\text {ai }} \mathrm{ha}^{-1}$ & 0.0 & 0.0 & 0.0 & 20.0 & 15.0 & 10.2 \\
\hline Fluazifop-p-butyl $12.5 \mathrm{~g}$ ai ha ${ }^{-1}$ & 0.0 & 0.0 & 0.0 & 5.0 & 0.0 & 0.0 \\
\hline Fluazifop-p-butyl $25 \mathrm{~g}$ ai ha ${ }^{-1}$ & 0.0 & 0.0 & 0.0 & 20.0 & 10.0 & 7.7 \\
\hline Clethodim $12 \mathrm{~g}$ ai ha ${ }^{-1}$ & 0.0 & 0.0 & 0.0 & 15.0 & 10.0 & 5.2 \\
\hline Clethodim $24 \mathrm{~g}$ ai ha ${ }^{-1}$ & 0.0 & 0.0 & 0.0 & 25.0 & 20.0 & 17.7 \\
\hline Haloxyfop-methyl $6 \mathrm{~g}$ ai ha-1 & 0.0 & 0.0 & 0.0 & 30.0 & 25.0 & 20.0 \\
\hline Haloxyfop-methyl $12 \mathrm{~g}$ ai ha ${ }^{-1}$ & 0.0 & 0.0 & 0.0 & 45.0 & 100.0 & 100.0 \\
\hline Unhoed check & 0.0 & 0.0 & 0.0 & 0.0 & 0.0 & 0.00 \\
\hline Hoed check & 0.0 & 0.0 & 0.0 & 100.0 & 100.0 & 100.0 \\
\hline
\end{tabular}


The lowest tepraloxydim rate resulted in yellowing of $B$. ruziziensis plants, with recovery of the forage plant and disappearance of symptoms on the last evaluation. The highest rate of this herbicide caused marked injury to the plants and symptoms still persisted on the last evaluation, with a mean percent control of $10.2 \%$. Similar results have been reported by Brighenti et al. (2008), who observed substantial injury to B. ruziziensis after application of 20 and $40 \mathrm{~g}$ ai ha ${ }^{-1}$ tepraloxydim. Less expressed symptoms were observed after application of fluazifop-p-butyl and the symptoms had disappeared in the last evaluation when a herbicide rate of $12.5 \mathrm{~g}$ ai ha ${ }^{-1}$ was applied. Silva et al. (2006b) found that a fluazifop-p-butyl rate of $15 \mathrm{~g}$ ai ha ${ }^{-1}$ applied to grass-soybean intercrops resulted in a similar productivity as that observed for the monoculture and still permitted pasture reestablishment. The highest fluazifop-p-butyl rate (25 $\mathrm{g}_{\text {ai }} \mathrm{ha}^{-1}$ ) caused chlorosis in the forage plants, with values of $20 \%$ at 12 DAHA. Recovery of the plants was observed and percent control decreased to $7.7 \%$ at 40 DAHA. The clethodim rate of $12 \mathrm{~g}$ ai ha ${ }^{-1}$ also provoked yellowing of the plants, but percent control was low on the last evaluation (5.2\%). The highest clethodim rate markedly affected the forage plants and mean percent control was still high on the last evaluation at 40 DAHA (17.7\%). Haloxyfopmethyl caused the highest phytotoxicity to the forage plants among all herbicides tested. The lowest rate $\left(6 \mathrm{~g}\right.$ ai ha $\left.{ }^{-1}\right)$ of this herbicide resulted in a percent control of $30 \%$ on the first evaluation. Although the forage plants recovered, this value was still expressive on the last evaluation (20\%). The highest haloxyfop-methyl rate (12 g ai $\mathrm{ha}^{-1}$ ) caused complete forage eradication as early as on the second evaluation.

Table 2: Mean values of density (DB), height $(\mathrm{HB})$ and fresh $\left(\mathrm{FMB}_{1}\right)$ and dry phytomass (DMB) of $B$. ruziziensis plants at 95 days after sowing, fresh phytomass of $B$. ruziziensis at 25 days after sunflower harvest $\left(\mathrm{FMB}_{2}\right)$, fresh phytomass of sunflower (FMS) at 110 days after sowing, and seed productivity (P).

\begin{tabular}{|c|c|c|c|c|c|c|c|}
\hline \multirow[b]{2}{*}{ Treatment } & DB & $\mathrm{HB}$ & $\mathrm{FMB}_{1}$ & DMB & $\mathrm{FMB}_{2}$ & FMS & $P$ \\
\hline & $\begin{array}{c}\text { plants } \\
0.25 \mathrm{~m}^{-2}\end{array}$ & $\mathrm{~cm}$ & $\mathrm{~kg} \mathrm{ha}^{-1}$ & $\mathrm{~kg} \mathrm{ha}^{-1}$ & $\mathrm{~kg} \mathrm{ha}^{-1}$ & $\mathrm{~kg} \mathrm{ha}^{-1}$ & $\mathrm{~kg} \mathrm{ha}^{-1}$ \\
\hline Tepraloxydim $10 \mathrm{~g}_{\text {ai }} \mathrm{ha}^{-1}$ & $62.7 \mathrm{~A}$ & $34.9 \mathrm{~B}$ & $2120.0 \mathrm{~B}$ & $320.0 \mathrm{C}$ & $22,390.0 \mathrm{E}$ & $344,767.8 \mathrm{~A}$ & $1758.9 \mathrm{~A}$ \\
\hline Tepraloxydim $20 \mathrm{~g}$ ai ha ${ }^{-1}$ & $59.0 \mathrm{~A}$ & $25.9 \mathrm{~B}$ & $260.0 \mathrm{C}$ & $40.0 \mathrm{C}$ & $18,710.0 \mathrm{E}$ & $348,214.2 \mathrm{~A}$ & 1925.3 A \\
\hline Fluazifop-p-butyl $12.5 \mathrm{~g}$ ai ha ${ }^{-1}$ & $65.5 \mathrm{~A}$ & $44.3 \mathrm{~A}$ & $3460.0 \mathrm{~B}$ & $540.0 \mathrm{~B}$ & $32,320.0 A$ & A 46,375.0 A & $1845.0 \mathrm{~A}$ \\
\hline Fluazifop-p-butyl $25 \mathrm{~g}$ ai ha-1 & $68.2 \mathrm{~A}$ & $35.4 \mathrm{~B}$ & $740.0 \mathrm{C}$ & $120.0 \mathrm{C}$ & $22,500.0 \mathrm{E}$ & 3 45,803.5 A & $1939.2 \mathrm{~A}$ \\
\hline Clethodim $12 \mathrm{~g}$ ai ha ${ }^{-1}$ & $69.7 \mathrm{~A}$ & $36.9 \mathrm{~B}$ & $2500.0 \mathrm{~B}$ & $400.0 \mathrm{~B}$ & $17,400.0 \mathrm{E}$ & B 46,920.0 A & $2046.4 \mathrm{~A}$ \\
\hline Clethodim $24 \mathrm{~g}$ ai ha ${ }^{-1}$ & $53.5 \mathrm{~A}$ & $14.2 \mathrm{C}$ & $0.0 \mathrm{C}$ & $0.0 \mathrm{C}$ & $16,670.0$ & B 48,675.0 A & A 1969.6 A \\
\hline Haloxyfop-methyl $6 \mathrm{~g}$ ai ha-1 & $44.5 \mathrm{~A}$ & $33.1 \mathrm{~B}$ & $440.0 \mathrm{C}$ & $60.0 \mathrm{C}$ & $24,160.0 \mathrm{E}$ & $349,464.2 \mathrm{~A}$ & $1841.0 \mathrm{~A}$ \\
\hline Haloxyfop-methyl $12 \mathrm{~g}$ ai ha ${ }^{-1}$ & $53.7 \mathrm{~A}$ & $20.3 \mathrm{C}$ & $0.0 \mathrm{C}$ & $0.0 \mathrm{C}$ & $15,992.0 \mathrm{E}$ & $348,437.5 \mathrm{~A}$ & 1830.3 A \\
\hline Unhoed check & $77.5 \mathrm{~A}$ & $46.5 \mathrm{~A}$ & $5700.0 \mathrm{~A}$ & $940.0 \mathrm{~A}$ & $37,240.0$ & A 40,437.5 B & $31440.0 \mathrm{~B}$ \\
\hline Hoed check & $0.0 \mathrm{~B}$ & $0.00 \mathrm{D}$ & $0.0 \mathrm{C}$ & $0.0 \mathrm{C}$ & $0.0 \mathrm{C}$ & $49,792.5 \mathrm{~A}$ & $2175.0 \mathrm{~A}$ \\
\hline CV (\%) & 34.6 & 23.3 & 101.9 & 95.0 & 32.4 & 5.3 & 8.4 \\
\hline
\end{tabular}

Means in the same column followed by the same letters did not differ significantly from one another (Scott-Knott test at $5 \%$ probability). 
Application of the herbicides did not influence the density of $B$. ruziziensis plants at 64 DAS (Table 2). With respect to forage height, all herbicide rates applied reduced the size of the plants, except for the lowest fluazifop-p-butyl rate. Fresh and dry phytomass of the forage plants decreased with increasing herbicide rate. No forage production was observed at 95 DAS after application of the highest rates of clethodim and haloxyfop-methyl. Similar results have been reported by Brighenti et al. (2008), who observed complete eradication of the forage plants when a haloxyfopmethyl rate of $12 \mathrm{~g}_{\text {ai }} \mathrm{ha}^{-1}$ was applied.

Although some of the treatments caused marked injuries to the forage plants, pasture reestablishment was observed 25 days after sunflower harvest for all treatments. The lowest fluazifop-p-butyl rate resulted in the highest amount of phytomass $\left(32,320 \mathrm{~kg} \mathrm{ha}^{-1}\right)$, with no significant difference when compared to the unhoed check $\left(37,240 \mathrm{~kg} \mathrm{ha}^{-1}\right)$. With respect to fresh phytomass and seed productivity of sunflower, the forage grass interfered with the unhoed check treatment, with significantly lower values being obtained when compared to the other treatments. This finding indicates the need for application of reduced rates of herbicides in order to temporarily delay the growth of the forage grass and to avoid competition with the crop plantation.

Experiment 2: The rates of tepraloxydim and fluazifop-p-butyl applied were highly selective for the sunflower crop, which showed no visual symptom of injury (Table 3). The lowest rate of tepraloxydim resulted in a mean percent control of the forage grass of $15 \%$ at 14 DAHA. Recovery of the plants was observed thereafter, with a percent control of approximately $2.0 \%$ at 40 DAHA. However, the highest rate of this herbicide promoted a more effective control of the forage plants, reaching $22 \%$ at 14 DAHA. Visual symptoms of injury were still observed on the last evaluation. The lowest rate of fluazifop-p-butyl resulted in only mild symptoms of phytotoxicity, with a percent control of $5 \%$ at 14 DAHA, declining to $2.6 \%$ at 21 DAHA and disappearing at 40 DAHA. The rate of $25 \mathrm{~g}$ ai ha $^{-1}$ of this herbicide caused chlorosis in the forage plants, with a percent control of $25 \%$ at 14 DAHA. Recovery of the plants was observed during the study period, reaching $10 \%$ at 40 DAHA.

Table 3: Mean percentage of phytotoxicity to the sunflower plants and percent control of $B$. ruziziensis at 14, 21 and 40 days after herbicide application (DAHA).

\begin{tabular}{|c|c|c|c|c|c|c|}
\hline \multirow[t]{2}{*}{ Treatment } & \multicolumn{3}{|c|}{ \% Phytotoxicity } & \multicolumn{3}{|c|}{$\%$ Control } \\
\hline & 14 DAHA & 21 DAHA & 40 DAHA & 14 DAHA & $21 \mathrm{DAHA}$ & 40 DAHA \\
\hline Hoed check & 0.0 & 0.0 & 0.0 & 100.0 & 100.0 & 100.0 \\
\hline Unhoed check & 0.0 & 0.0 & 0.0 & 0.0 & 0.0 & 0.0 \\
\hline Tepraloxydim $10 \mathrm{~g}$ ai ha ${ }^{-1}$ & 0.0 & 0.0 & 0.0 & 15.0 & 7.3 & 2.0 \\
\hline Tepraloxydim $20 \mathrm{~g}$ ai ha-1 & 0.0 & 0.0 & 0.0 & 22.0 & 15.0 & 9.0 \\
\hline Fluazifop-p-butyl $12.5 \mathrm{~g}$ ai ha ${ }^{-1}$ & 0.0 & 0.0 & 0.0 & 5.0 & 2.6 & 0.0 \\
\hline Fluazifop-p-butyl $25 \mathrm{~g}$ ai ha-1 & 0.0 & 0.0 & 0.0 & 25.0 & 15.0 & 10.0 \\
\hline
\end{tabular}

Sunflower height or forage density at 64 DAS was not influenced by the treatments (Table 4). The tepraloxydim rates led to a reduction in B. ruziziensis height, which differed from the unhoed check. 
A reduction in fresh and dry forage phytomass was observed with increasing herbicide rate. The highest tepraloxydim rate caused death of the aerial parts of the forage plants at 95 DAS, with no phytomass production being observed. The sunflower crop was influenced by the forage plant. The unhoed check produced 45,166 $\mathrm{kg} \mathrm{ha}^{-1}$ of fresh matter, whereas this value exceeded $51,547 \mathrm{~kg} \mathrm{ha}^{-1}$ for the other treatments. Production of marked amounts of forage plants at 25 days after sunflower harvest was observed for the treatments with $10 \mathrm{~g}$ ai ha ${ }^{-1}$ tepraloxydim and with the two fluazifop-p-butyl rates.

Table 4: Mean values of sunflower height (HS) at 90 days after sowing, forage density (DB), forage height $(\mathrm{HB})$, fresh $\left(\mathrm{FMB}_{1}\right)$ and dry phytomass (DMB) of $B$. ruziziensis at 95 days after sowing, fresh mass of sunflower (FMS) at 110 days after sowing, and fresh mass of B. ruziziensis $\left(\mathrm{FMB}_{2}\right)$ at 25 days after sunflower harvest.

\begin{tabular}{|c|c|c|c|c|c|c|c|}
\hline \multirow[b]{2}{*}{ Treatment } & $\mathrm{HS}$ & $\mathrm{DB}$ & $\mathrm{HB}$ & $\mathrm{FMB}_{1}$ & DMB & FMS & $\mathrm{FMB}_{2}$ \\
\hline & $\mathrm{cm}$ & $\begin{array}{c}\text { plants } \\
0.25 \mathrm{~m}^{-2}\end{array}$ & $\mathrm{~cm}$ & $\mathrm{~kg} \mathrm{ha}^{-1}$ & $\mathrm{~kg} \mathrm{ha}^{-1}$ & $\mathrm{~kg} \mathrm{ha}^{-1}$ & $\mathrm{~kg} \mathrm{ha}^{-1}$ \\
\hline Hoed check & $176.6 \mathrm{~A}$ & $0.0 \mathrm{~A}$ & $0.0 \mathrm{C}$ & $0.0 \mathrm{~B}$ & $0.0 \mathrm{C}$ & $53,595.2 \mathrm{~A}$ & $0.0 \mathrm{~B}$ \\
\hline Unhoed check & $183.7 \mathrm{~A}$ & $35.3 \mathrm{~A}$ & $45.3 \mathrm{~A}$ & $6213.3 \mathrm{~A}$ & $746.6 \mathrm{~A}$ & $45,166.8 \mathrm{~B}$ & $24,783.3 \mathrm{~A}$ \\
\hline Tepraloxydim $10 \mathrm{~g}$ ai ha ${ }^{-1}$ & $189.2 \mathrm{~A}$ & $21.6 \mathrm{~A}$ & $32.4 \mathrm{~B}$ & $1173.3 \mathrm{~B}$ & $160.0 \mathrm{~B}$ & $53,571.4 \mathrm{~A}$ & $17,966.6 \mathrm{~A}$ \\
\hline Tepraloxydim $20 \mathrm{~g}_{\text {ai }} \mathrm{ha}^{-1}$ & $193.7 \mathrm{~A}$ & $26.3 \mathrm{~A}$ & $24.7 \mathrm{~B}$ & $0.0 \mathrm{~B}$ & $0.0 \mathrm{C}$ & $52,523.8 \mathrm{~A}$ & $7000.0 \mathrm{~B}$ \\
\hline Fluazifop-p-butyl $12.5 \mathrm{~g}$ ai ha ${ }^{-1}$ & $183.5 \mathrm{~A}$ & $29.6 \mathrm{~A}$ & $41.4 \mathrm{~A}$ & 2666.6 B & $346.6 \mathrm{~B}$ & $53,346.1 \mathrm{~A}$ & $18,833.3 \mathrm{~A}$ \\
\hline Fluazifop-p-butyl $25 \mathrm{~g}$ ai ha-1 & $198.6 \mathrm{~A}$ & $44.0 \mathrm{~A}$ & $46.7 \mathrm{~A}$ & 1893.3 B & $266.6 \mathrm{~B}$ & $51,547.6 \mathrm{~A}$ & $18,730.3 \mathrm{~A}$ \\
\hline CV (\%) & 5.6 & 56.1 & 18.8 & 66.7 & 65.7 & 3.3 & 28.9 \\
\hline
\end{tabular}

Means in the same column followed by the same letters did not differ significantly from one another (Scott-Knott test at 5\% probability).

\section{CONCLUSIONS}

All herbicide treatments were selective for the sunflower crop. The use of reduced rates of graminicides is a feasible option to delay the growth of $B$. ruziziensis, reducing its competitive ability against sunflower. All herbicide rates applied suppressed the growth of $B$. ruziziensis, permitting subsequent pasture reestablishment. However, tepraloxydim (20 g ai ha $\left.{ }^{-1}\right)$, clethodim (24 g ai ha $\left.{ }^{-1}\right)$, and haloxyfop methyl ( $12 \mathrm{~g}$ ai ha ${ }^{-1}$ ) promoted poorer recovery of the forage grass.

\section{ACKNOWLEDGEMENTS}

This study was supported by Fundação de Amparo à Pesquisa do Estado de Minas Gerais (FAPEMIG) and Conselho Nacional de Desenvolvimento Científico e Tecnológico (CNPq), Brazil. 


\section{REFERENCES}

Aidar, H., Thung, M., Oliveira, I.P., Kluthcouski, J., Carneiro, G.E.S., Silva, J.G., Del Peloso, M.J., 2000. Bean production and white mould incidence under no-till system. Improvement Cooperative 43: 150-151.

Brighenti, A.M., Souza Sobrinho, F., Martins, C.E., Rocha, W.S.D., 2007. Integração lavourapecuária-floresta. In: L. C. T. Yamagushi, L. C. R. Mendes, I. B. Lima, C. C. Rodrigues, M. L. Resende. Aspectos Econômicos e Ambientais da Produção de Leite. Juiz de Fora: Embrapa Gado de Leite, pp. 107-124.

Brighenti, A.M., Souza Sobrinho, F., Rocha, W.S.D., Castro, C., Martins, C.E., Costa, T.R., 2008. Estabelecimento da Brachiaria ruziziensis consorciada com girassol utilizando doses reduzidas de graminicidas. CD Rom. In: Congresso Nordestino de Produção Animal. Aracaju, SE: Sociedade Nordestina de Produção Animal.

Cobucci, T., Kluthcouski, J., Aidar, H., 2001. Sistema Santa Fé: produção de forragem na entressafra. In: Anais of the Workshop Internacional do Programa de Integração Agricultura e Pecuária para o Desenvolvimento Sustentável das Savanas Tropicais Sul-americanas. Santo Antônio de Goiás, GO: Embrapa Arroz e Feijão, pp. 125-135.

Gronwald, J.W., 1991. Lipid biosynthesis inhibitors. Weed Science 39: 435-449.

Konish, T., Shinohara, K., Yamada, K., Sasaki, Y., 1996. Acetyl-CoA carboxylase in higer plants: most plants other than gramineae have both the prokaryotic and eukaryotic forms of this enzyme. Plant and Cell Physiology 37: 117-122.

Kluthcouski, J., Cobucci, T., Aidar, H., Yokoyama, L.P., Oliveira, I.P., Costa, J.L.S., Silva, J.G., Vilela, L., Barcellos, A.O., Magnabosco, C.U., 2000. Sistema Santa Fé - Tecnologia Embrapa: integração lavoura-pecuária pelo consórcio de culturas anuais com forrageiras, em áreas de lavoura, nos sistemas direto e convencional. Santo Antônio de Goiás: Embrapa Arroz e Feijão Circular Técnica 38, pp. 28.

Martius, C., Tiessen, H., Vleck, P.L.G., 2001. The management of organic matter in tropical soils: What are the priorities? Nutrient Cycling in Agroecosystems 61: 1-6.

Miranda, J.C.C., Miranda, L.N., Vilela, L., Vargas, M.A., Carvalho, A.M., 2001. Manejo da micorriza arbuscular por meio de rotação de culturas nos sistemas agrícolas dos cerrados. Planaltina: Embrapa Cerrados Documento Técnico 42, pp. 3.

Sociedade Brasileira da Ciência das Plantas Daninhas, 1995. Procedimentos para instalação e análise de experimentos com herbicidas. Londrina, PR: SBCPD, pp. 42.

Silva, A.C., Ferreira, L.R., Silva, A.A., Paiva, T.W.B., Sediyama, C.S., 2004. Efeitos de doses reduzidas de fluazifop-p-butil no consórcio entre soja e Brachiaria brizantha. Planta Daninha 22: 429-435.

Silva, A.C., Carneiro, J.E.S., Ferreira, L.R., Cecon, P.R., 2006a. Consórcio entre feijão e Brachiaria brizantha sob doses reduzidas de graminicidas. Planta Daninha 24: 71-76.

Silva, A.C., Freitas, F.C., Ferreira, L.R., Freitas, R.S., 2006b. Dessecação pré -colheita de soja e Brachiaria brizantha consorciadas com doses reduzidas de graminicidas. Pesquisa agropecuária brasileira 41: 37-42.

Vilela, L., Miranda, J.C.C., Sharma, R.D., Ayarza, M.A., 1999. Integração lavoura-pecuária: atividades desenvolvidas pela Embrapa Cerrados. Planaltina: Embrapa Cerrados Documento 9. pp. 31.

Vilela, L., Macedo, M.C.M., Martha Junior, G.B., Kluthcouski, J., 2003. Benefícios da Integração Lavoura Pecuária. In: J., Kluthcouski; L.F. Stone, H. Aidar. Integração lavoura-pecuária. Santo Antônio de Goiás: Embrapa Arroz e Feijão, pp. 145-170. 


\title{
APLICACIÓN DE DOSIS REDUCIDAS DE HERBICIDAS INHIBIDORES DE LA ACCASE EN GIRASOL CONSOCIADO CON Brachiaria ruziziensis
}

\author{
RESUMEN
}

El objetivo de este estudio fue evaluar la tolerancia del girasol (Helianthus annuus) a los herbicidas inhibidores de la acetil-coenzima A carboxilasa (ACCase) y retardar temporariamente el crecimiento de la especie forrajera (Brachiaria ruziziensis), evitando la competición con el girasol y permitiendo el restablecimiento posterior de las pasturas. En los dos experimentos fue utilizado el diseño de bloques al azar con cuatro repeticiones. Los tratamientos aplicados fueron Experimento 1:

I) $10 \mathrm{~g}$ ia ha ${ }^{-1}$ tepraloxydim; II) $20 \mathrm{~g}_{\text {ia ha }}{ }^{-1}$ tepraloxydim; III) $12,5 \mathrm{~g}_{\text {ia }} \mathrm{ha}^{-1}$ fluazifop-p-butil, IV) $25 \mathrm{~g}_{\text {ia }} \mathrm{ha}^{-1}$ fluazifop-p-butil, v) $12 \mathrm{~g}$ ia ha-1 clethodim; VI) 24 $\mathrm{g}$ ia ha $\mathrm{h}^{-1}$ clethodim; VII) $6 \mathrm{~g}$ ia ha ${ }^{-1}$ haloxyfop-methyl, VIII) $12 \mathrm{~g}^{\text {ia }} \mathrm{ha}^{-1}$ haloxyfopmethyl IX) testigo sin carpir, X) testigo carpido.

Los tratamientos utilizados en el Experimento 2 fueron:

I) testigo carpido, II) testigo sin carpir III) $10 \mathrm{~g}_{\text {ia }} \mathrm{ha}^{-1}$ tepraloxydim; IV) $20 \mathrm{~g}$ ia $\mathrm{ha}^{-1}$ tepraloxydim, v) $12,5 \mathrm{~g}^{\text {ia ha }}{ }^{-1}$ fluazifop-p-butil, vI) $25 \mathrm{~g}$ ia ha $\mathrm{h}^{-1}$ fluazifop-pbutil.

Todos los herbicidas fueron selectivos para el cultivo del girasol. La utilización de dosis reducidas de herbicidas graminicidas es una opción viable para retardar el crecimiento de B. ruziziensis, reduciendo su capacidad competitiva con el girasol. Todas las dosis de herbicidas aplicadas suprimieron el crecimiento de Brachiaria, permitiendo el restablecimiento posterior de la pastura. Sin embargo, tepraloxydim $\left(20 \mathrm{~g}\right.$ ia ha $\left.\mathrm{h}^{-1}\right)$, clethodim $\left(24 \mathrm{~g}_{\text {ia }} \mathrm{ha}^{-1}\right)$,

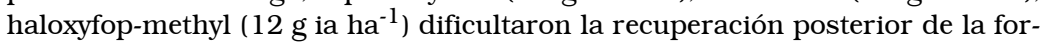
rajera.

\section{L`APPLICATION DE DOSES REDUITES D HERBICIDES INHIBITEURS DE L`ACCase DANS TOURNESOL ASSOCIE AVEC Brachiaria ruziziensis}

\author{
RÉSUMÉ
}

L'objectif de cette étude était d'évaluer la tolérance du tournesol (Helianthus annuus) a l'interdiction des herbicides inhibiteurs de l'acetil-coenzima A carboxilase (ACCase) et retarder temporairement la croissance de l'espece fourragere (Brachiaria ruziziensis), en évitant la compétition avec le tournesol et permettant le rétablissement ultérieur du pâturage. La conception dans des blocs aléatoires avec quatre répétitions a été utilisée dans les deux expériences. Les traitements suivants ont été appliqués dans l'Expérience 1:

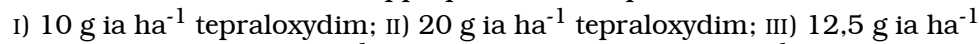
fluazifop-p-butil, Iv) $25 \mathrm{~g}$ ia ha- ${ }^{-1}$ fluazifop-p-butil, v) $12 \mathrm{~g}$ ia ha-1 clethodim; vI) $24 \mathrm{~g}$ ia ha-1 clethodim; VII) $6 \mathrm{~g}^{\text {ia ha }}{ }^{-1}$ haloxyfop-methyl, vIII) $12 \mathrm{~g}$ ia ha $\mathrm{h}^{-1}$ haloxyfop-methyl IX) a preuve sans sarclage et X) a preuve sarclé.

Les traitements utilisés dans l'Expérience 2 étaient

I) a preuve sarclé, II) a preuve sans sarclage III) $10 \mathrm{~g}_{\text {ia }} \mathrm{ha}^{-1}$ tepraloxydim; IV) $20 \mathrm{~g}_{\text {ia ha }}{ }^{-1}$ tepraloxydim, v) $12,5 \mathrm{~g}_{\text {ia ha }}{ }^{-1}$ fluazifop-p-butil e vI) $25 \mathrm{~g}_{\text {ia ha }}{ }^{-1}$ fluazifop-p-butil. 
Tous les herbicides étaient sélectifs pour la culture du tournesol. L'utilisation des doses réduites d'herbicides est une option viable pour retarder la croissance de B. ruziziensis, réduisant sa capacité compétitive avec le tournesol. Toutes les doses appliquées d'herbicides ont supprimé la croissance de B. ruziziensis, permettant le rétablissement ultérieur du pâturage. Cependant, tepraloxydim ( $20 \mathrm{~g}_{\text {ia ha }}{ }^{-1}$ ), clethodim ( $\left.24 \mathrm{~g}_{\text {ia }} \mathrm{ha}^{-1}\right)$, haloxyfop-methyl ( $12 \mathrm{~g}$ ia ha $\left.{ }^{-1}\right)$, ils ont gené le rétablissement ultérieur de la fourragere. 